\title{
Evaluation of Hybrid Course Implementation in Construction Engineering
}

\author{
Aliye Karabulut Ilgu \\ aliye@iastate.edu \\ Post-Doctoral Research Associate \\ Civil, Construction and Environmental Engineering \\ Iowa State University \\ Charles Jahren \\ cjahren@iastate.edu \\ W.A. Klinger Teaching Professor in Civil Engineering \\ Civil, Construction and Environmental Engineering \\ Iowa State University
}

\begin{abstract}
Engineering educators call for a widespread implementation of hybrid instruction to respond to rapidly changing demands of 21st Century ${ }^{1}$. In response to this call, a junior-level course in the Construction Engineering department entitled Construction Equipment and Heavy Construction Methods was converted into a hybrid instruction model. The overarching goal in the hybrid course development was to take the content that can be engaged outside the class to an online platform so that class time can be used more efficiently for authentic, realistic, open-ended problems and homework assignments. This study reports the design, development and evaluation of this hybrid course and provides practical implications for hybrid course development.
\end{abstract}

\section{Introduction}

Hybrid learning, interchangeably referred to as blended learning, can be defined, in its most generic sense, as an educational approach that combines online instruction with face-to- face instruction ${ }^{2,3}$. Because of its blending feature, hybrid format is also considered as the best of two worlds providing the benefits of both the online and face-to-face environments ${ }^{3}$. In hybrid learning, lectures can be replaced by interactive activities, which can be facilitated by teaching assistants under the supervision of the instructors. The professor then has more time to interact with individual students and enhance the quality of the course through sustained course development and innovation ${ }^{2,4}$.

When executed well, hybrid instruction provides several benefits at the student, faculty and institution level. Researchers argued that blended learning courses were in high demand because of the increased convenience and flexibility, and learning outcomes were higher than traditional and face-to-face counterparts. Similarly, the majority of the faculty was satisfied with their blended learning courses and blended learning provided benefits at the institutional level by improving the efficiency of classroom use ${ }^{5}$. A recent meta analysis of online education by the U.S. Department of Education also revealed that students in online learning conditions performed modestly better than students in face-to-face conditions; and students in hybrid learning conditions performed better than both completely online and face-to-face conditions ${ }^{6}$. 
Prior research indicates that people choose blended or hybrid instruction for three main reasons: 1) improved pedagogy, 2) increased access/flexibility 3) increased cost effectiveness ${ }^{7,8}$. Hybrid learning approaches increase the opportunities for active learning strategies, group work, and learner-centered pedagogies ${ }^{9}$. Learner flexibility and convenience is also of growing importance as more non-traditional students, who have job and family commitments, seek additional education $^{7,10}$. In addition, hybrid teaching holds the potential to address the cost problem by "taking faculty out of the easily automated business of delivery of information and allowing them to refocus their attention with students on critical thinking skills”1.

Maximizing success in a hybrid learning environment requires reconceptualization of teaching, learning and assessing. As Peercy and Cramer noted "successful hybrid teaching cannot be a mish-mash of traditional lecturing with some online content but rather a thoughtful re-design of

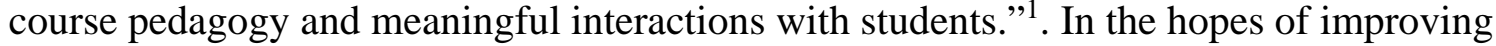
learning while providing some flexibility for students and instructors, a junior level construction engineering course, entitled Construction Equipment and Heavy Construction Methods, was converted from traditional face-to-face instruction to hybrid format starting in the summer of 2012. This study reports the design, development and evaluation of this hybrid course and provides practical implications for hybrid course development.

\section{Description of the Hybrid Format}

The overarching goal in the hybrid course development was to take the content that can be engaged outside the class to an online platform so that class time can be used more efficiently for open-ended problems and homework assignments. The course syllabus was carefully analyzed to identify what could easily go online and what needed to be covered in the class (See Appendix A)

\section{Online Activities}

Online activities for this hybrid course involved lectures and modules. Lectures that were normally given in a traditional face-to-face classroom format by the instructor are made into online videos through screen recording and voice-over narration. Many times, lectures that are given in class are merely a transfer of knowledge with limited student interaction. Those types of lectures are a good fit for online lecture videos and allow students to obtain information that they need outside of classroom time. This, in turn, frees up face-to-face classroom time that can be used to apply the knowledge obtained through the lecture. The online lectures in this hybrid course introduced the course concepts through visually enhanced, relatively short videos by checking comprehension along the way. Interested readers can see a sample lecture video in here: http://www.screencast.com/t/A9MCvuwlyhOG. Our experience has also shown that it takes less time to cover the same amount of material online in comparison to face-to-face lecture.

After the instructor screen recorded a given topic, an instructional design assistant engaged in some post-production, which included three main tasks: chunking the video, adding visual enhancement, and adding comprehension questions. In the online course design literature, it is recommended that the videos should be around five minutes to keep students engaged in the material ${ }^{15}$. Bearing this in mind, the videos were chunked into relatively short, manageable parts. Then, the presentations were visually enhanced by adding images, highlighting important 
information based on the principles of the cognitive theory of multimedia learning ${ }^{16}$. Finally, comprehension questions checking students' understanding of the material were integrated. Students had two attempts for these questions and they received immediate feedback whether they got the right answer or not. These scores are recorded in the course management system, i.e. Blackboard Learn, and included as part of the overall course grade. In total, there were nine online lecture videos in this hybrid course.

Online modules are interactive exercises that demonstrate how to solve problems in construction engineering and allow students to practice solving similar problems in a step-by- step, interactive, scaffolded learning environment. Twelve modules were developed using the e- learning software, Lectora, for this hybrid course. Four main instructional design decisions were made for development online modules: 1) scaffolded problem solving, 2) step-by-step problem solving, 3) immediate explanatory feedback, and 4) multiple attempts (See Figure 1).

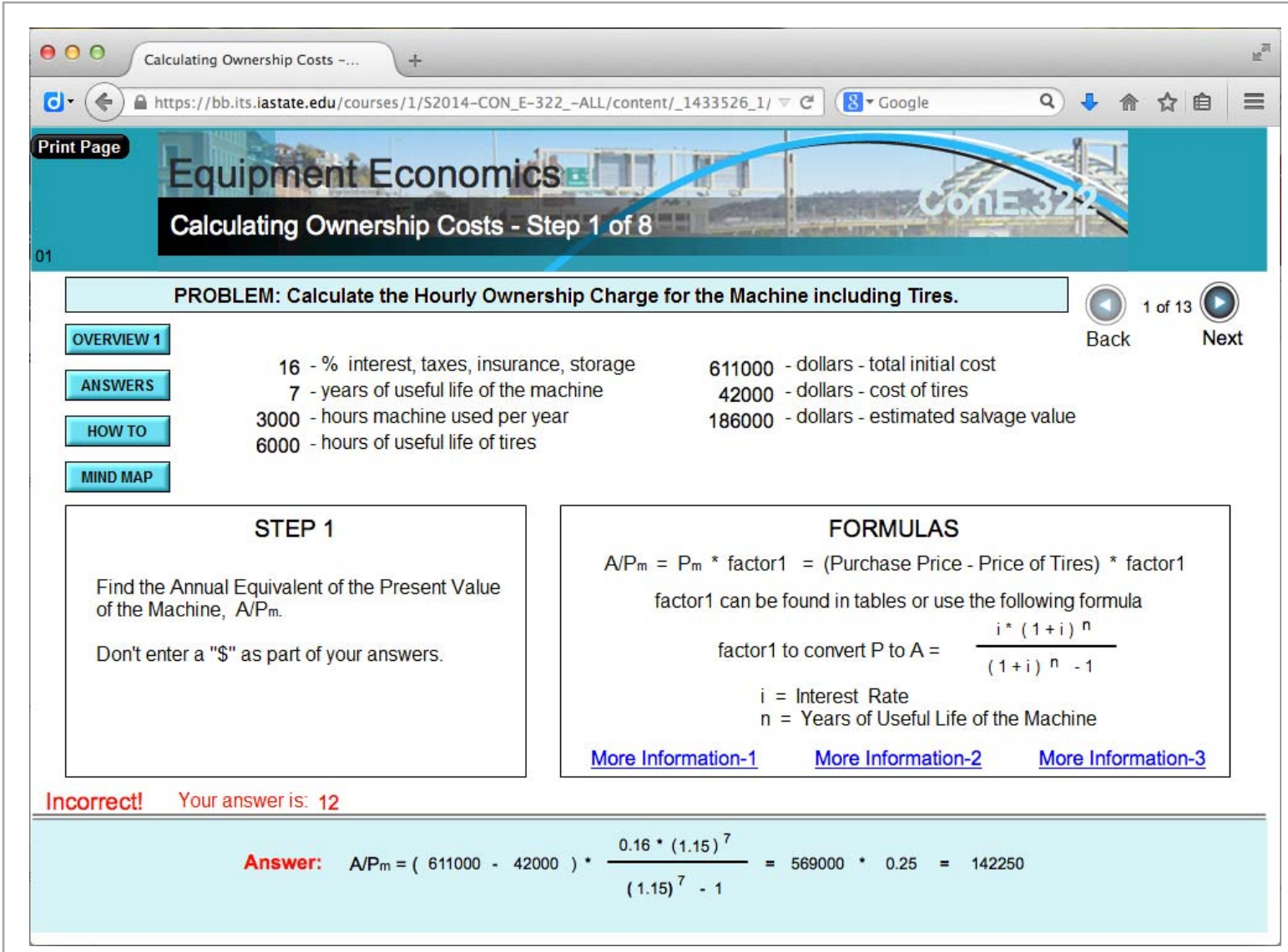

Figure 1. Example online module Link: http://www.screencast.com/t/MznFBUMh6aF

To scaffold student learning in complex problem solving, worked-examples were provided to demonstrate how to solve a particular problem. These worked examples were called "how-to 
videos” and provided as on-demand help options. Students had the opportunity to see the solution process of a problem with a different set of data if they had difficulty solving the problem.

A complex problem statement was chunked into multiple steps and students were asked to submit their answers for each step. The underlying reason for taking students through the steps of a problem was to help them understand what they needed to do to reach a solution to a complex problem. They were expected to implement this strategy in open-ended problems they solved during in-class sessions.

Students were allowed two attempts in a given question to get the right answer. This was particularly important for questions that require a numeric entry in order to avoid any calculation errors. Students also received automated explanatory feedback to ensure they knew what the right answer was and they did not carry mistakes over.

\section{Face-to-Face Activities}

Taking the lecture and problem practice parts of the course to the online platform forced the instructional design team to reflect more on the in-class activities. Homework assignments and in-class activities were revised and converted into more open-ended, real-life exercises on which students can work in small groups under the supervision of the instructor and teaching assistants. In these activities, the instructor and the teaching assistants played a facilitative role rather than directing the instruction. For example, three homework assignments were converted to illdefined problem format. Homework assignments were also chosen from real construction projects taken place on and around campus. Other in-class activities involved students presenting information, analyzing real-life scenarios and providing alternative solutions, working on handson projects.

\section{Research Methodology}

The summative evaluation included in this paper was collected in Spring 2014, in which 19 students were enrolled. Out of these 19 students, 13 students participated in focus group interviews. Pseudo names are used throughout this report to protect the identity of the participants. All the interviews were administered during a class period in week 14 of a 15 -week semester in Fall 2014 in the regular classroom where students had met throughout the semester. A semi-structured interview protocol including questions about the main aspects of the course was followed allowing room for follow-up questions. The interviews took an average of 30 minutes. All the focus group sessions were audio-recorded and transcribed verbatim for analysis. The data were manually coded for recurring themes and categories.

\section{Results and Discussion}

\section{Student Identified Benefits of Hybrid Instruction}

Focus group interview findings pointed out that hybrid instruction provided two major benefits for students: flexibility and pacing of the learning. Students repeatedly referred to the flexibility of the hybrid format as an advantage. They indicated that they enjoyed being able to do the 
online activities on their own time without being restricted to classroom time as pointed out in this comment:

I liked hybrid learning, as far as, you only have to come in to class certain amount of days and then the rest you do it in your own time, which is really good. It just adds a lot of flexibilities into my schedule, which is the biggest thing, so a lot of open times. And I can do it, you know, either early in the morning or late at night and I don't really have to worry about with everything else I have going on. (Ray, Focus Group 1, p. 1)

Another flexibility that hybrid format brought was that students were able to plan and work ahead if they preferred to do so. All the online lectures and modules in this course were made available from the beginning of the semester but they were closed after the due dates. Students appreciated this flexibility because they could work ahead if they knew they had a busy week coming up as Brad said "If I have an hour gap, I'd like to fill it with something. And the ability to sit down and work something like this, I feel like, yeah, just knock it out” (Brad, Focus Group 1, p.2)

Another advantage of hybrid format identified by students was the ability to pace their own learning. They repeatedly referred to being able to pause, rewind, and replay as one positive aspect of hybrid learning. For example, Sam mentioned that he was able to go back and review the material when he did not understand it or skipped parts of the video if he was confident in his knowledge in that area. Sam noted:

[I liked] being able to pause it. If you need to replay it, if you didn't get it all the first time, you can replay it and go back over it whereas other stuff you can also click ahead if you already know everything. So, it gives you that option. Kind of go in your pace. (Sam, Focus Group 3, p. 2).

The online component also provided opportunities for students to run the lecture videos while they are working on their homework assignments so that they could practice what they learned immediately. For instance, Brad mentioned how having videos available helped him do the homework assignments.

While you are working on the module, being able to have the video up while you are working on the video at the same time; it will play along and go step by step to keep up instead of frantically writing a bunch of notes while you are sitting in the class (Brad, Focus Group 1, p. 6)

\section{Student Identified Challenges of Hybrid Instruction}

The analysis of focus group interviews revealed three main challenges in this hybrid course: technical issues, course organization, and communication issues. Although the instructional design team tried to do their best to test and debug all the online activities, they were unable to avoid some technical glitches which hindered student learning at times as Brad pointed:

The frustrating part was when you go through all that spending 15 minutes on the problem realizing that you had the right answer all along and then the computer was wrong...I just wanted 
to throw a chair to the computer, so yeah, it is just a lot of weird things in the system. (Brad, Focus Group 1, p. 4)

Another challenge for students in this hybrid course was related to course organization. The way the syllabus was designed was not consistent in terms of when things were due. In other words, there was not a specific day of the week that students would do an online activity and another day for in-class activities which created confusion at times. For example, Bruce noted:

One of the things I found frustrating was coming to class and thinking that I had my homework done because I had it in my hand. And then oh, we had a module due last night. Just having to be aware of the, there is in-class and out-of-class, I didn't care for that [others approving]. That got kind of confusing sometimes. (Bruce, Focus Group 2, p. 6)

One final challenge identified by students was communication issues. Because students missed the opportunity of asking questions while watching the lectures and modules, they needed to compensate for that via online communication. However, there was not a set agreement between students and the teaching staff about how soon emailed questions would be answered, which sometimes resulted in delayed communication.

Overall, the findings of this study indicate that hybrid instruction has the potential to transform engineering education by creating "space" in face-to-face meeting times for more open- ended, realistic problems that can be worked on in small groups by adding advantages like flexibility and learner pacing. However, hybrid course design requires a careful reconsideration of learning objectives, learning activities, assessments, as well as communication channels. Based on the findings of this study, we can make the following practical recommendations for those who are interested in converting their traditional face-to-face classroom to a hybrid format.

1. Make the online component required

2. Provide scaffolding for online activities

3. Reduce the number of technical issues to a minimum

4. Meaningfully weave the online and face-to-face activities

5. Train students for the new format

6. Provide a well-established and consistent structure

7. Communicate with students in new ways

\section{Limitations and Recommendations for Future Work}

Like most studies, this study encountered some limitations that should be taken into consideration when interpreting the results. One limitation concerns the low number of participants. Because the hybrid format was implemented in this particular course, we had to limit the participant pool to the students who were enrolled in the course. However, four more courses are currently in the process of conversion from traditional face-to-face format to hybrid instruction. A larger scale study involving all the hybrid courses might give a more generalizable data set informing the effectiveness of hybrid instruction. 


\section{Bibliography}

1. Peercy, P. S. and Cramer, S. M., "Redefining Quality in Engineering Education Through Hybrid Instruction," Journal of Engineering Education 100 (2011): 625-629.

2. Garrison, D. R. and Heather K., "Blended Learning: Uncovering its Transformative Potential in Higher Education,” The Internet and Higher Education 7 (2004): 95-105.

3. Lamport, M. A. and Hill, R. J. "Impact of Hybrid Instruction on Student Achievement in Post-Secondary Institutions: A Synthetic Review of the Literature,” Journal of Instructional Research, 1 (2012), accessed June 12, 2014 http://www.gcu.edu/Academics/Journal-of-Instructional-Research/Impact-of-Hybrid-Instruction--.php

4. Kenny, J. and Newcombe, E., “Adopting Blended Learning Approach: Challenges Encountered and Lessons Learned in an Action Research Study,” Journal of Asyhncronous Learning Networks 15 (2011): 45-57

5. Dziuban, C. D., Hartman, J. L., and Moskal, P. D. "Blended Learning." edited by Center for Applied Research EDUCAUSE, 2004, accessed June 12, 2014 https://net.educause.edu/ir/library/pdf/erb0407.pdf

6. Means, B., Toyama, Y., Murphy, R., Bakia, M., and Jones, K., "Evaluation of Evidence-Based Practices in Online Learning: A Meta-Analysis and Review of Online Learning Studies." Washington DC: U.S.Department of Education, Office of Planning, Evaluation, and Policy Development, 2010.

7. Graham, C. R. "Blended Learning Systems: Definition, Current Trends, and Future Directions.". In Handbook of Blended Learning: Global Perspectives, Local Designs, edited by C. J. Bonk and C. R. Graham, 3-21. San Francisco, CA: Pfeiffer Publishing, 2006.

8. Vignare, K., "Longitudinal Success Measures of Online Learning Students at the Rochester Institute of Technology." In Elements of Quality Online Education: Practice and Direction, edited by J. Bourne and J. C. Moore, 261-78. Needham, MA: Sloan Consortium, 2002.

9. Collis, B., "Course Redesign for Blended Learning: Modern Optics for Technical Professionals," International Journal of Continuing Engineering Education and Lifelong Learning, 13 (2003): 22-38.

10. Kaleta, R., Skibba, K. and Joosten, T., "Discovering, Designing, and Delivering Hybrid Courses." In Blended Learning: Research Perspectives, edited by A. G. Picciano and C. D. Dziuban, 111-43. Needam, MA: The Sloan Consortium, 2007. 


\section{Appendix A Course Schedule}

\section{Con E 322 - Fall 2014 \\ Construction Equipment and \\ Heavy Construction Methods \\ T \& Th 12:10 - 2:00 PM}

Hoover 1312, Town 0322

\begin{tabular}{|c|c|c|c|c|c|}
\hline Prd & Day & Date & Topic (Matches Chapter Title in Text Book and Notes) & $\begin{array}{l}\text { Classroom } \\
\text { or Online }\end{array}$ & $\begin{array}{l}\text { Reading } \\
\text { Material }\end{array}$ \\
\hline 1 & $\mathrm{~T}$ & $8 / 26$ & $\begin{array}{l}\text { Introduction; Machines Make It Possible Lecture } \\
\text { Assigned: Online Module \#1 Equipment Cost-Fundamental } \\
\text { Concepts \& Equipment Economics }\end{array}$ & $\begin{array}{l}\text { In-class } \\
\text { and Online }\end{array}$ & Ch 1 \\
\hline 2 & $\mathrm{TH}$ & $8 / 28$ & $\begin{array}{l}\text { Hourly Equipment Cost Lab } \\
\text { Assigned: HW \#1 Cost of Equipment Problems } \\
\text { Due@ Noon: Module \#1 }\end{array}$ & In-class & Ch 2 \\
\hline 3 & $\overline{\mathrm{T}}$ & $9 / 2$ & $\begin{array}{l}\text { Mobile Equipment Power Requirements Lecture } \\
\text { Assigned: Online Module \#3 Mobile Equipment Power } \\
\text { Requirements Example Problems, HW \#2 Machine } \\
\text { Equipment Power Requirements Homework } \\
\text { Due@ Noon: HW \#1 }\end{array}$ & $\begin{array}{l}\text { In-class } \\
\text { and Online }\end{array}$ & Ch 6 \\
\hline 4 & $\mathrm{TH}$ & $9 / 4$ & $\begin{array}{l}\text { Equipment Productivity Fundamentals Lecture } \\
\text { Assigned: Online Lecture Excavators, HW \#2a Equipment } \\
\text { Productivity Assignment } \\
\text { Due @ Noon: Module \#3 }\end{array}$ & $\begin{array}{l}\text { In-class } \\
\text { and Online }\end{array}$ & Ch 9 \\
\hline 5 & $\bar{T}$ & $9 / 9$ & $\begin{array}{l}\text { Trucks and Hauling Equipment Lecture } \\
\text { Assigned: Online Module \#5 Excavator Example Problems } \\
\text { Due@ Noon: HW \#2 and \#2a, Online Excavator Lecture }\end{array}$ & $\begin{array}{l}\text { In-class } \\
\text { and Online }\end{array}$ & Ch 10 \\
\hline 6 & $\mathrm{TH}$ & $9 / 11$ & $\begin{array}{l}\text { Howe Hall Mass Excavation Problem Lab } \\
\text { Assigned: Online Module \#7 Short Queuing Problem, HW \#4 } \\
\text { Howe Hall Excavation Lab Problem and \#4a Excavator Home } \\
\text { Problem } \\
\text { Due@ Noon: Module \#5 }\end{array}$ & $\begin{array}{c}\text { In-class } \\
\text { and Online }\end{array}$ & $\begin{array}{l}\text { CAT } \\
\text { Handbook }\end{array}$ \\
\hline 7 & $\bar{T}$ & $9 / 16$ & $\begin{array}{l}\text { Short Queueing Problem Lab } \\
\text { Assigned: Online Module \#8, HW \#5 Queuing Home Problem } \\
\text { Due @ Noon: Module \#7 and HW \#4a }\end{array}$ & $\begin{array}{c}\text { In-class } \\
\text { and Online }\end{array}$ & \\
\hline 8 & $\mathrm{TH}$ & $9 / 18$ & Grading Lab & In-class & \\
\hline 9 & $T$ & $9 / 23$ & $\begin{array}{l}\text { NO CLASS } \\
\text { Assigned: Online Lecture Dozers and Online Module \#10 } \\
\text { Dozers (two example problems), HW \#9 Bulldozer Home } \\
\text { Problem } \\
\text { Due @ Noon: Module \#8, HW \#5 (leave in box outside Town } \\
\text { Engineering Room 024) } \\
\text { CAREER FAIR }\end{array}$ & Online & $\mathrm{Ch} 7$ \\
\hline 10 & $\mathrm{TH}$ & $9 / 25$ & $\begin{array}{l}\text { Long Queuing Problem Lab } \\
\text { Assigned: Homework \#6 Long Queuing Lab Problem } \\
\text { Due@ Noon: HW \#9, Module \#10, Online Lecture Dozers }\end{array}$ & In-class & \\
\hline$\overline{11}$ & $\bar{T}$ & $9 / 30$ & $\begin{array}{l}\text { NO CLASS } \\
\text { Assigned: Online Scrapers Lecture, Online Module \#11 } \\
\text { Scraper Selection (Performance Charts), HW \#7 Scraper } \\
\text { Home Problem }\end{array}$ & Online & $\begin{array}{l}\text { CAT } \\
\text { Handbook } \\
\text { and Ch } 8\end{array}$ \\
\hline 12 & $\mathrm{TH}$ & $10 / 2$ & $\begin{array}{l}\text { Exam 1 Review, Scraper Example Problem } \\
\text { Due @ Noon: Online Scrapers Lecture, Module \#11 and HW } \\
\text { \#6 }\end{array}$ & In-class & \\
\hline
\end{tabular}




\begin{tabular}{|c|c|c|c|c|c|}
\hline 13 & $\mathrm{~T}$ & $10 / 7$ & $\begin{array}{l}\text { Exam \#1 } \\
\text { Assigned: Online Module \#13 Howe Hall Backfill Design } \\
\text { Due @ Noon: HW \#7 }\end{array}$ & In-class & \\
\hline 14 & $\mathrm{TH}$ & $10 / 9$ & $\begin{array}{l}\text { Backfill Process Design Lab } \\
\text { Assigned: Homework \#10 Howe Hall Backfill Lab Problem } \\
\text { Due@ Noon: Module \#13 }\end{array}$ & $\begin{array}{l}\text { In-class } \\
\text { and Online }\end{array}$ & $\begin{array}{l}\text { CAT } \\
\text { Handbook }\end{array}$ \\
\hline 15 & $\bar{T}$ & $10 / 14$ & $\begin{array}{l}\text { Backfill Process Design Lab Cont'd } \\
\text { Assigned: Online Concrete Placement Lecture } \\
\text { Due by END of class: HW \#10 }\end{array}$ & $\begin{array}{l}\text { In-class } \\
\text { and Online }\end{array}$ & $\begin{array}{l}\text { CAT } \\
\text { Handbook } \\
\text { Ch } 16\end{array}$ \\
\hline 16 & $\mathrm{TH}$ & $10 / 16$ & $\begin{array}{l}\text { Concrete Placement Lab } \\
\text { Assigned: Online Pile Driving Lecture, HW \#15 Class } \\
\text { Presentations } \\
\text { Due @ Noon: Online Concrete Placement Lecture }\end{array}$ & In-class & Ch 18 \\
\hline 17 & $\overline{\mathrm{T}}$ & $10 / 21$ & $\begin{array}{l}\text { NO CLASS } \\
\text { Assigned: Online Crane Lecture; Module \#17a Crane Safety }\end{array}$ & Online & Ch 17 \\
\hline 18 & $\mathrm{TH}$ & $10 / 23$ & $\begin{array}{l}\text { Pile Driving Lab } \\
\text { Assigned: Online Module \#17b Crane Load Chart Example } \\
\# 1, \text { HW \#15 } \\
\text { Due@ Noon Module \#17a, Online Pile Driving Lecture }\end{array}$ & $\begin{array}{l}\text { In-class } \\
\text { and Online }\end{array}$ & Ch 17 \\
\hline 19 & $T$ & $10 / 28$ & $\begin{array}{l}\text { Crane Load Chart Lab \#1 } \\
\text { Assigned: HW \#11 Crane Example Problem and } 12 \text { Crane } \\
\text { Capacity Problem } \\
\text { Due@ Noon: Module \#17b, Online Crane Lecture } \\
\text { Due@ @end of class: HW \#11 and \#12 }\end{array}$ & $\begin{array}{l}\text { In-class } \\
\text { and Online }\end{array}$ & \\
\hline 20 & $\mathrm{TH}$ & $10 / 30$ & $\begin{array}{l}\text { Field Trip - Caterpillar Dealer - Ziegler, Altoona } \\
\text { Assigned: Homework \#16 and Module \#16 Tower Cranes }\end{array}$ & In-class & \\
\hline 21 & $\bar{T}$ & $11 / 4$ & $\begin{array}{l}\text { Automatic Machine Guidance Lecture } \\
\text { Assigned: Online Module \#19 Crane Load Chart Example \#2 } \\
\text { Due@ Noon: Module \#16 and Homework \#16 }\end{array}$ & In-class & \\
\hline 22 & $\mathrm{TH}$ & $11 / 6$ & $\begin{array}{l}\text { Crane Load Chart Lab \#2 } \\
\text { Assigned: Homework \#13 Crane Capacity Problem and \#13A } \\
\text { Crane Lab Problem } \\
\text { Due@ Noon: Module \#19 } \\
\text { Due@ end of class: Homework } 13 \text { and 13A }\end{array}$ & $\begin{array}{l}\text { In-class } \\
\text { and Online }\end{array}$ & \\
\hline 23 & $T$ & $11 / 11$ & Crane Sequencing Lab & In-class & \\
\hline 24 & $\mathrm{TH}$ & $11 / 13$ & EXAM \#2 & $\begin{array}{l}\text { In-class } \\
\text { Exam }\end{array}$ & \\
\hline 25 & $\overline{\mathrm{T}}$ & $11 / 18$ & $\begin{array}{l}\text { Automatic Machine Guidance Guest Speaker } \\
\text { Assigned: Online Asphalt Paving Lecture and Online } \\
\text { Concrete Paving Lecture }\end{array}$ & In-class & \\
\hline 26 & $\mathrm{TH}$ & $11 / 20$ & $\begin{array}{l}\text { NO CLASS } \\
\text { Assigned: Geotechnical Materials, Compaction, Stabilization, } \\
\text { and Testing Online Lecture } \\
\text { Due @ Noon: Online Asphalt Paving Lecture and Online } \\
\text { Concrete Paving Lecture }\end{array}$ & Online & $\begin{array}{l}\text { Ch } 4 \& \mathrm{Ch} \\
5\end{array}$ \\
\hline \multicolumn{6}{|c|}{$11 / 24-11 / 28$ THANKSGIVING BREAK NO CLASS } \\
\hline 27 & $\bar{T}$ & $12 / 2$ & $\begin{array}{l}\text { Construction Process Design Lab } \\
\text { Assigned: Homework \#14 Construction Practice Design } \\
\text { Homework } \\
\text { Due@ Noon: Online Geotech Lecture }\end{array}$ & In-class & $\begin{array}{l}\text { CAT } \\
\text { Handbook }\end{array}$ \\
\hline 28 & $\mathrm{TH}$ & $12 / 4$ & $\begin{array}{l}\text { Construction Process Design Lab } \\
\text { Due @ end of class: Homework \#14 }\end{array}$ & In-class & $\begin{array}{l}\text { CAT } \\
\text { Handbook }\end{array}$ \\
\hline
\end{tabular}




\begin{tabular}{|c|c|c|l|l|l|}
\hline 29 & $\mathrm{~T}$ & $12 / 9$ & $\begin{array}{l}\text { Group Presentations } \\
\text { Due: Homework \#15 }\end{array}$ & In-class & In-class \\
\hline 30 & $\mathrm{TH}$ & $12 / 11$ & $\begin{array}{l}\text { Group Presentations } \\
\text { Due: Homework \#15 }\end{array}$ & Finals week 12/15-12/19 FINAL EXAM - time TBD \\
\hline
\end{tabular}

